\title{
Yes, we can! Encouraging responsible management through effective CSR communication
}

Book or Report Section

Accepted Version

Garnelo-Gomez, I. and Saraeva, A. (2019) Yes, we can! Encouraging responsible management through effective CSR communication. In: Farache, F., Grigore, G., Stancu, A. and McQueen, D. (eds.) Responsible People: The Role of the Individual in CSR, Entrepreneurship and Management Education. Palgrave Macmillan, Cham, Switzerland, pp. 115134. ISBN 9783030107390 Available at https://centaur.reading.ac.uk/83281/

It is advisable to refer to the publisher's version if you intend to cite from the work. See Guidance on citing.

Published version at: https://link.springer.com/chapter/10.1007/978-3-030-10740-6_6

Publisher: Palgrave Macmillan

All outputs in CentAUR are protected by Intellectual Property Rights law, including copyright law. Copyright and IPR is retained by the creators or other copyright holders. Terms and conditions for use of this material are defined in the End User Agreement. 


\section{CentAUR}

Central Archive at the University of Reading

Reading's research outputs online 


\title{
Yes, we can! Encouraging responsible management through effective CSR communication
}

\author{
Irene Garnelo-Gomez and Anastasiya Saraeva
}

\section{Introduction}

Business schools have gradually started incorporating corporate social responsibility-related modules into MBA programmes (Christensen et al. 2007; Larran and Andrades 2014). A study published by Larran et al. (2017) found that $64 \%$ of top 100 MBA programmes ranked by the Financial Times offer stand-alone courses on corporate social responsibility (CSR) and ethics. Although this percentage appears to have increased in recent years, there is still a need to proactively integrate responsibility into business programmes (Waddock and Lozano 2013), and to encourage and develop education in responsible management (PRME 2007; Millar and Price 2018). This is particularly critical for business productivity. For example, effective CSR training (e.g. for managers) has a significant impact on business, specifically on brand image and the financial value of an organisation as, for instance, "it is possible that properly trained managers can ensure sustainability while companies and their shareholders maximize their financial value" (López-Pérez et al. 2017, 442).

CSR practice suggests that it is essential that managers understand key aspects of CSR communication in order to create stakeholder awareness (Du et al. 2010). We thus argue that a similar approach should be followed in education, and, in particular, when delivering CSR modules to MBA students (referred to, in this chapter, as programme members). For instance, Henley Business School (University of Reading, UK), offers three modules related to CSR as part of its MBA curriculum. In one of them, namely Reputation and Responsibility, lecturers engage programme members in experiential learning (Kolb 1984). As such, programme members travel to Cape Town (South Africa) to conduct a consultancy project for local NGOs. In doing so, they not only develop their responsible management skills, but experience responsibility challenges in a novel and distinctive manner. Through immersing themselves in the daily lives of NGOs, MBA programme members help organisations to identify a responsibility challenge, analyse the problem, and offer a managerial solution. Most importantly, by engaging in conversations with diverse groups of individuals, from charity staff to beneficiaries, programme members have the fortunate opportunity of receiving first-hand insights on CSR practice; these insights then enrich their awareness about responsibility issues.

Henley Business School is also a participant in the Principles for Responsible Management Education (PRME) initiative. This platform, created in 2007 and coordinated by the UN Global Compact, aims to provide business students with the necessary awareness and understanding of sustainability and CSR to develop their ability to deliver change in the future (PRME 2007). As such, Henley Business School reports to the UN how the principles of PRME are being addressed, and how the research and teaching carried out at the institution facilitate the dialogue around CSR issues; in other words, how to create CSR knowledge and how to communicate it (Henley Business School 2017).

In spite of the growing tendency for CSR-related modules to be integrated into MBA curriculum, little is known about efficient ways to communicate CSR in management education (Setó-Pamies and Papaoikonomou 2016). Most importantly, and to the best of the authors' knowledge, no study 
currently exists that explores the effects of the interplay between module content and lecturer in CSR communication-neither generally nor in the particular context of MBA education.

In this conceptual chapter, we reflect on practical CSR issues in MBA education and focus on the role of the individual in CSR practice. Specifically, we investigate how to encourage managers at the individual level to embrace CSR activities and become responsible agents who deliver change in the future. We then propose a theoretical framework, with the aim of shedding light on effective CSR communication in management education.

\section{Communicating CSR in MBA programmes}

Various dimensions of CSR, such as citizenship, governance, and working conditions, are key drivers of corporate reputation (Reputation Institute 2018). These highlight the importance of communicating CSR in an effective way. According to Dawkins (2005), organisations should develop a clear strategy when designing CSR communications, and a CSR message should be tailored for each stakeholder group -that is, one based on information needs, interests, and preferred channels of communication.

Du et al. (2010) agree with Dawkins and include stakeholder characteristics in their Framework of CSR Communication. However, the authors focus their attention on the content of the message, which often emphasises what the company is doing, rather than focusing on the social issue itself. They suggest that when developing CSR communications, companies should indeed focus on the importance of the social issue but also on other factors. In particular, they mention the commitment the organisation has with the issue, the impact the company is making by getting involved, the motives driving the company to collaborate, and the congruence between the social issue and the business itself. Nevertheless, according to Morsing (2006), organisations should not merely inform stakeholders about CSR issues; rather, in order to build trust, companies might interact with stakeholders on a continuous basis. The scholar argues then that by establishing an "interaction strategy" (as a complement to the "information strategy"), stakeholders will positively identify with the company and the company will better understand stakeholders' expectations, contributing to the development of CSR strategies and the effective communication thereof.

We believe that a similar approach should be followed when communicating CSR in education. There should be a clear strategy behind the CSR communication, and the content of the message ought to focus on teaching business students how to embed social issues into the company's strategies. This argument is also aligned with existing approaches to CSR education. For instance, building on Lozano et al. (2006), we agree that the design of CSR-related modules should include not only relevant content, but also relevant learning processes that could encourage students to critically analyse CSR issues and the role of business in society.

Furthermore, we agree with Morsing's idea of establishing an "interaction strategy", which, in the context of this chapter, would involve communicating CSR messages not only in a classroom but also by interacting with the social issue itself and building relationships with key stakeholders. We also agree with Sims (2002), who suggests that ethics can be communicated effectively if an experiential approach is followed and if lecturers are able to create an environment in which students feel safe to share their experiences. In our view, the combination of a well-designed content that allows 
programme members to experience CSR, with the opportunity for interaction with others, both in the classroom and outside of it, leads to the creation of an effective message.

\section{Effective CSR message}

Despite the significant existing research on CSR communications in the corporate world (Du et al. 2010; Tata and Prasad 2015) and in the education arena (Cornelius et al. 2007; Stubbs and Schapper 2011), little is known about how to effectively communicate CSR issues to MBA programme members. For the purpose of this conceptual chapter, we build on previous studies (Giacalone and Thompson 2006; Lozano et al. 2006) and argue that one of the key aspects when communicating CSR in higher education relates to the content of the CSR module.

In our view, and in accordance with the PRME principles (2007), the materials designed for communicating CSR in MBA programmes should not merely create awareness of past and current CSR issues. Rather they should aim to drive behavioural change as well. We believe in the idea that by the end of the programme, MBA programme members should have developed the necessary knowledge and belief around CSR issues that would translate at a personal level, and, as a consequence, at their place of work. As mentioned above, the first step to achieving this aim involves designing effective module content.

A few universities design the content of CSR modules not only to promote student acquisition of knowledge on social responsibility issues, but also to implement this knowledge through real case scenarios. Henley Business School's approach to MBA education could be an example of excellence in this area. As mentioned in the introduction, they offer three CSR-related modules as part of their MBA curriculum, one of them called Reputation and Responsibility. As part of this module, MBA programme members travel to Cape Town, where they work as consultants for a week with local charities, with the purpose of resolving existing organisational challenges. In doing so, they build an understanding of how to tackle social issues, which gives them strategies on how to apply CSR (Brew 2002; Stubbs and Schapper 2011). By working with these charities, MBA programme members interact with stakeholders affected by social issues, and it is through these experiences that they are able to build ideas and thoughts around social responsibility (Kolb 1984; Sims 2002).

The approach followed at Henley Business School allows MBA programme members to reflect on societal problems and to engage with them at a personal level. This learning approach contrasts with the standard design and content of CSR modules, which encourages students to examine CSR issues from a business perspective (Stubbs and Schapper 2011). We believe that by communicating CSR messages addressing both the personal and professional identities of MBA programme members, students will be more effectively engaged with module content which, ultimately, will lead to positive behavioural change.

While the content of the CSR message when communicating to MBA programme members is vital, we believe that the question of who is communicating the message is of particular importance (McDonald 2004). Indeed, the early studies on CSR communication have shown that effective messages may not necessarily lead to desired behaviours if they are not communicated by the "right" messenger. An example of this relates to Victoria State (Australia), where the local government attempted to proactively communicate the importance of wearing helmets while cycling. This resulted in a decrease 
of the number of young people cycling (and therefore exercising) and, as a consequence, a decrease in the overall national health rate (De Jong 2012). The question is, would have the outcome been different if the message was communicated by a different source?

In the next section of this chapter, we explore the notion of the messenger (i.e. lecturer), who has been hardly examined in the CSR arena (Groza et al. 2011), and who we argue is crucial to effectively communicate CSR in MBA programmes.

\section{Identification with lecturer as key to effective CSR education}

Despite the discussed importance of communicating CSR module content as an effective message, CSR education involves much more than "conveying information" (Benson 1994; Northcott 2001). In fact, various student surveys show that, despite advances in module materials, there are other attributes that make the module highly influential (Douglas et al. 2006; Butt and Rehman 2010). One of these attributes is who the lecturer is and whether and how students relate to them.

One may argue that the pedagogy literature has received a significant attention to the role of a teacher in higher education (Murray and Macdonald 1997; Hill et al. 2003). However, we believe that the role and significance of a lecturer as a messenger (i.e. an entity that communicates a message directly to the audience-see Saraeva 2017) in the context of education remains unclear and requires further investigation.

In general, communication literature suggests that a messenger appears as a critical "touchstone", which individuals use to evaluate or judge received messages (Groza et al. 2011). At the same time, various studies support that messengers can lead to changes in people's attitudes and behaviours (Lafferty and Goldsmith 1999; Ruth and York 2004). We argue that a communication approach that understands lecturers as messengers in CSR education may help MBA programme members to actively engage with the module content, which could contribute to greater commitment to CSR practice outside the classroom.

\section{Unpacking the "messenger"}

One of the most discussed attributes of a messenger is credibility (Lafferty and Goldsmith 1999; Jones et al. 2003). For example, Fishbein and Ajzen (2011) find that individuals are more likely to engage in positive behaviours influenced by the information from a credible messenger (Mackenzie and Lutz 1989; Miller and Krosnick 2000). This is in line with the pedagogy literature, as subject knowledge, expertise, and organisation skills-that is, credibility-are found to be essential characteristics of a lecturer (Eggen and Kauchak 1993; TooToonchi et al. 2002).

While, on the whole, lecturer credibility can positively impact how CSR messages are being perceived by MBA programme members, it is not yet clear why people still tend to react differently to the same lecturer. The communication literature suggests that perceptions of lecturers (as messengers) could be triggered by unobservable determinants, such as enthusiasm, energy and/or humour (Guolla 1999), impressions (Jones et al. 2003), or similarity between an individual and a messenger (Kwon et al. 2015), rather than credibility alone. For instance, Jones and Gerard $(1967,436)$ find that "when his [messenger's] values do not coincide with those of his audience, the force of his message is reduced". In other words, individuals would be more affected by what messengers communicate if there was a 
perceived overlap in values and/or beliefs between a messenger and the audience (Basil 1996; Cheong and Morrison 2008).

Following the discussion on similarity, we suggest that a possible way of exploring underlying determinants of how individual MBA programme members perceive CSR lecturers may lie in studies related to identification with the messenger (Basil 1996; Saraeva 2017). In order to integrate the concept of identification with a messenger into the context of CSR education, it is important to review previous approaches to the phenomenon.

\section{Burke's drama theory}

Burke (1969) is one of the early theorists who indirectly focused on the role of a messenger. While studying drama, Burke finds that when the audience feels a certain connection-rapport-with a character on stage, this significantly induces the persuasiveness of their acting. Hence, we argue that when an MBA programme member feels a certain connection with a lecturer (similar to how the audience connects to a character on stage), then the communicated message about CSR (i.e. module content) may have a higher persuasive impact on the individual (Guolla 1999). Indeed, following the CSR education purpose, it seems crucial to ensure that the module content is well perceived. However, Burke does not elaborate on how the abovementioned rapport may impact individuals' behaviours. Furthermore, and building on the PRME principles (2007), MBA programmes (involving CSR communication) are expected to drive significant behavioural change among programme members. Thus, the drama theory lacks sufficient evidence on how a lecturer (as a messenger) could positively impact students' awareness of and behaviours towards CSR practice.

\section{Bandura's social learning theory}

Further insight in understanding the rapport between a lecturer and MBA programme members is drawn from social learning theory (Bandura 1969). Bandura argues that people's behaviours are influenced or could be changed through learning from "role models", with whom an individual may feel a certain overlap of values. In other words, Bandura suggests that when a person identifies with the role model, they are more likely to engage in promoted behaviours. Drawing from this theory, a CSR lecturer may appear (deliberately or inadvertently) as a role model to MBA programme members (TooToonchi et al. 2002). Thus, when a programme member feels identified with a lecturer, they would be more likely to engage in CSR behaviours and become agents who deliver change in the future.

\section{Saraeva's identification with messenger}

The identification with messenger framework by Saraeva (2017) is one of most recent developments in this area, which is successfully incorporated into corporate communication context. Saraeva believes that the framework may help to better understand how people perceive messages, and, in turn, to explain why they react differently to communication. She further argues that people's reactions and behaviours are driven by interactions between messages and various levels of identification with messengers.

Although the model of identification with messenger is developed and tested in the context of 
corporate communication about reputation, we believe that this framework is useful to the current context of CSR education. In particular, we argue that an interplay between module content (message) and identification with lecturer (messenger) may significantly influence MBA programme members' engagement with the CSR module, and, in turn, affect members' pro-CSR behaviours in the future (e.g. commitment to CSR practice).

Although establishing the role of MBA programme members' identification with a lecturer seems crucial, we believe that it is also important to explore consequences of the proposed interplay between module content and identification with a lecturer in communicating CSR to MBA programme members. In the next section of this chapter, we further address the proposed interplay and discuss possible outcomes of effective CSR communication in MBA education.

\section{Message-messenger interplay and CSR commitment}

We have previously established that a CSR message may have a significant impact on MBA programme members when communicated in a way that addresses both the individuals' self-reflection and the business perspective. Building on the theory of reasoned action (Fishbein and Ajzen 2011) and the identification with messenger framework (Saraeva 2017), we believe that the interaction between identification with a lecturer and a CSR message may influence programme members' commitment to CSR practice.

Building on Garnelo-Gomez (2017), commitment in the context of responsibility is understood as high levels of engagement with the issues of consideration and long-term expressions of responsible behaviour. In this chapter, behaviours towards CSR practice involve engaging in CSR issues outside the classroom. This, in turn, may lead MBA programme members to becoming agents of change, which in our view includes actively reacting to CSR issues in the workplace.

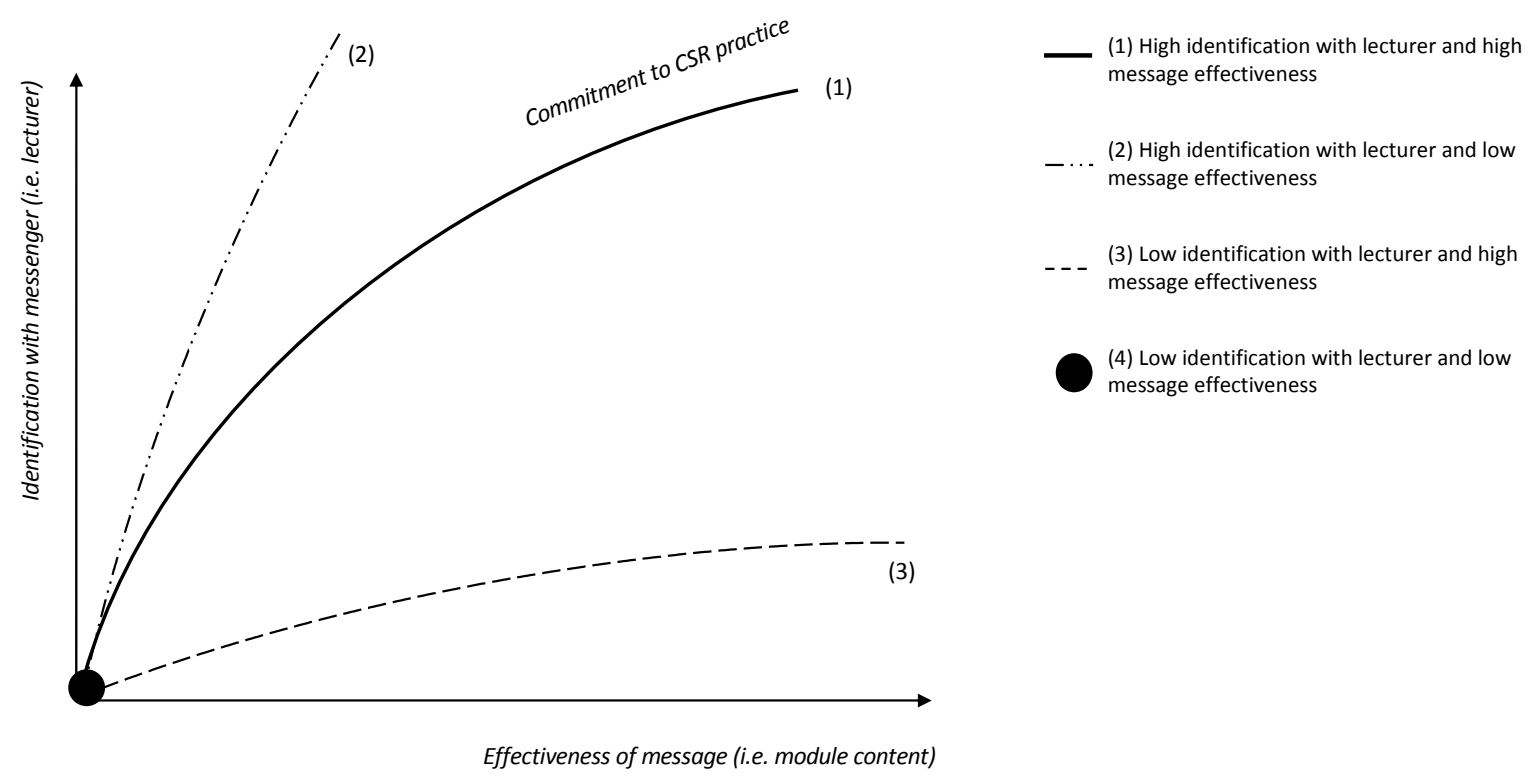

Figure 1. Conceptual representation of an interplay between effectiveness of message (module content) and identification with messenger (lecturer). 
Bringing together messages and messengers in the context of CSR education, we propose a framework of a dynamic interplay between module content and identification with lecturer and their combined impact on commitment to CSR practice (see Figure 1).

Previous studies on CSR and commitment have focused on understanding how competent CSR strategies and CSR communications could increase employee organisational commitment (Turker 2009; Du et al. 2010). We argue that this relationship between employees' commitment and CSR could be addressed from an earlier and alternative point of view. For instance, commitment could be understood as an antecedent instead of as a consequence of CSR strategies (i.e. employees' commitment to CSR could lead to a more effective CSR strategy and communication). By reaching what for the purpose of this chapter could be called a "perfect case scenario" (see Figure 1 path (1)effective message and high levels of identification with the messenger), MBA programme members would become the committed employees who would lead change and encourage the development of appropriate and efficient CSR strategies. In this case, employee commitment would lead to efficient CSR, which ultimately drives positive organisational performance (McWilliams et al. 2006). For example, a highly effective CSR message in the classroom would involve bringing real-life case studies to encourage students to critically analyse CSR issues and the role of business in society. Moreover, by explicitly communicating their values and beliefs as well as experience of CSR, lecturers would be able to establish a rapport with their students, which will arouse identification.

Another possible outcome of the proposed interplay would relate to the communication of a less effective or non-effective CSR message from the lecturer, whom MBA programme members feel highly identified with (see Figure 1 path (2)). Given the high identification with a lecturer, one could expect MBA programme members to be strongly affected by the delivery of the module content. However, a less effective message would probably lead to a limited engagement with the CSR module and, in turn, scarce CSR experience outside the classroom. Interestingly, studies on identification with messenger suggest that identification may raise people's awareness and trigger intentions to change behaviours (see Basil 1996; Brown and Basil 2010). Thus, it can be suggested that in this scenario a possible (positive) consequence would be an increase of MBA programme members' intentions to further explore CSR topics as well as find ways to engage in responsible behaviours outside the classroom.

Looking at the third possible scenario (see Figure 1 path (3)-effective CSR message and low or nonexistent level of identification with the lecturer), we suggest that the possibility of the MBA programme members becoming committed to CSR practice would be limited. In particular, we expect students to understand, debate, and engage with the CSR message when in the classroom, but not necessarily to become agents of change in the long term. The communication literature, however, suggests that people tend to find messages more persuasive in situations when they are highly involved in a particular issue (Golob et al. 2008). Moreover, recent advances in CSR research suggest that individuals tend to engage in responsible behaviours if responsibility is somehow part of their personal identity (Garnelo-Gomez 2017). In other words, people who have CSR principles at the core of their identity (i.e. personal values and beliefs related to the defence of human rights, the environment, etc.) would be highly influenced by the communicated message, regardless of who the messenger is and how they feel towards them. Therefore, we argue that with the obtained knowledge (from module content) and personal values and beliefs, MBA programme members would be more 
likely to adopt and implement CSR strategies at their workplace, as well as become the agents of change (Hemingway and Maclagan 2004; Hemingway 2005).

Finally, in the less desirable scenario (see Figure 1 path (4)-low levels of identification and less effective or non-effective CSR message), MBA programme members may develop a limited understanding and engagement with CSR issues. This may ultimately lead to lower levels of commitment to CSR practice-to include minor engagement with responsibility issues, short-term expressions of responsible behaviour, and limited application of knowledge outside the classroomwhich would not comply with the PRME (2007) and the existing idea of effective CSR teaching (Sims 2002; Lozano et al. 2006). However, we believe that scenario (4) is highly unlikely to appear in CSRrelated modules, especially in MBA education. More than 16,000 worldwide programmes (including MBA level) are committed to the PRME principles to "equip today's business students with the understanding and ability to deliver change tomorrow" (PRME 2007). Therefore, we believe that institutions participating in this initiative and beyond are increasingly interested in high-quality CSR teaching and learning.

To sum up, we believe that the proposed theoretical framework may help to anticipate MBA programme members' commitment to CSR practice. This also fits well with the Principles for Responsible Management Education (PRME) initiative (2007), which emphasises the long-term CSR education effect on proactive CSR change. While the proposed framework indicates that scenario (1), with high identification with the lecturer and highly effective CSR module content, would be most desirable for CSR-related modules within the MBA curriculum, it should be noted that scenarios (2) and (3) could also lead to positive outcomes. This would be the case if MBA programme members had the intention to further explore issues related to CSR (as in scenario (2)) or if CSR principles were already part of who they are as individuals (i.e. if their personal values and beliefs were aligned with those of responsibility) (as in scenario (3)).

\section{Conclusion and suggestions for future research}

The growth of business schools' attention to CSR practice has led to an increasing integration of CSRrelated modules into the MBA curriculum. However, effective ways of communicating CSR to MBA programme members have been greatly overlooked in the literature. In this chapter, we offer a novel theoretical framework, which unpacks nuances in effective communication of CSR-related messages in management education as well as outlines essential link to managers' commitment to CSR practice outside the classroom.

The journey towards effective communication starts with the message. In order to communicate CSR effectively, those in charge of designing the curriculum should carefully consider the content of the CSR-related module. We also argue that this type of module should have the aim of not only creating awareness, but also of driving change in behaviour (PRME 2007). In our view, the content of the module should be designed in such a way that programme members are able to critically analyse CSR from a business perspective, but which also allows them to reflect on social issues at a personal level. One of the ways in which this could be achieved (which is already established, for example, at the University of Leeds, University of Warwick, Cass Business School and EDHEC Business School) entails following an experiential approach (i.e. addressing CSR issues in a real case scenario). By facilitating the interaction between MBA programme members and stakeholders affected by social issues, the 
former are able to build their own argument around social responsibility (Sims 2002), which could contribute not only to higher levels of awareness but also to engagement and commitment.

We believe that "a messenger always accompanies a message" (O'Rourke 2013, 78). Thus, this chapter argues that the identification that audiences (such as MBA programme members) feel towards the lecturer communicating with them is key to understanding how and why students engage with CSR (Groza et al. 2011). In other words, when MBA programme members feel they identify with the lecturer, they may find the module content more influential, which, in turn, may contribute to higher levels of engagement and commitment to CSR practice.

Building on the premise of CSR communication, we offer a novel theoretical framework, which integrates the preceding discussed concepts. As such, the model reflects a dynamic interplay between module content and identification with the lecturer and their combined influence on commitment to CSR practice. Given this chapter is conceptual, we call for future empirical research to test the proposed framework and to cover additional issues that could influence the effectiveness of CSR communication in the context of MBA education. We believe that it will help to understand how to engage and develop modules in responsible management (Millar and Price 2018), contributing in this way to the PRME's principles.

\section{Limitations}

In light of the proposed framework, we acknowledge several limitations. Although incorporating the notion of a lecturer seems crucial, the framework is limited to identification with the lecturer and, as such, disregards other messenger characteristics. Future research should consider including additional factors (e.g. lecturer credibility, personal values, communication skills) and address how they might influence MBA programme members' engagement with the module as well as their future commitment to CSR practice. Furthermore, the characteristics of the individual who receives the message could also be taken into account by future researchers. For instance, the personal values and beliefs of the MBA programme members, as well as their motivations towards CSR practice, could influence the way the message is understood and processed.

The narrow scope of this study-applied as it is to CSR education at MBA level-also represents an important limitation. While it is crucial that MBA programme members become committed managers, leading change and encouraging the development of appropriate and efficient CSR strategies, it is essential to explore wider educational contexts. CSR-related modules are also implemented at the undergraduate and postgraduate levels. Thus, future research could explore how the proposed interplay between module content and identification with the lecturer influences bachelor and masters students' commitment to CSR practice.

The acknowledgment of these limitations and the presentation of these recommendations for future research are based on what we believe is an existing gap in the field of CSR communication in MBA education. We consider that the empirical testing of the theoretical framework proposed in this chapter could shed light on how to effectively communicate CSR messages to MBA programme members with the purpose of not only transferring knowledge, but encouraging behavioural change and the increase in the number of responsible people. 


\section{References}

Bandura, Albert. 1969. "Social-learning Theory of Identificatory Processes." Handbook of Socialization Theory and Research 213: 262.

Basil, Michael D. 1996. "Identification as a Mediator of Celebrity Effects." Journal of Broadcasting \& Electronic Media 40, no. 4 (1996): 478-95.

Benson, M. J. 1994. "Lecture Listening in an Ethnographic Perspective." In Academic Listening: Research Perspectives, edited by John Flowerdew, 181-8. Cambridge University Press.

Brew, Angela. 2002. The Nature of Research: Inquiry in Academic Contexts. Routledge.

Brown, William J., and Michael D. Basil. 2010. "Parasocial Interaction and Identification: Social Change Processes for Effective Health Interventions." Health Communication 25, no. 6-7 (2010): 601602.

Burke, Kenneth. 1969. A Rhetoric of Motives. Vol. 178. University of California Press.

Butt, Babar Zaheer, and Kashif ur Rehman. 2010. "A Study Examining the Students Satisfaction in Higher Education." Procedia-Social and Behavioral Sciences 2, no. 2 (2010): 5446-50.

Cheong, Hyuk Jun, and Margaret A. Morrison. 2008. "Consumers' Reliance on Product Information and Recommendations found in UGC." Journal of Interactive Advertising 8, no. 2 (2008): 3849.

Christensen, Lisa Jones, Ellen Peirce, Laura P. Hartman, W. Michael Hoffman, and Jamie Carrier. 2007. "Ethics, CSR, and Sustainability Education in the Financial Times Top 50 Global Business Schools: Baseline Data and Future Research Directions." Journal of Business Ethics 73, no. 4: 347-68.

Cornelius, Nelarine, James Wallace, and Rana Tassabehji. 2007. "An Analysis of Corporate Social Responsibility, Corporate Identity and Ethics Teaching in Business Schools." Journal of Business Ethics 76, no. 1: 117-35.

Dawkins, Jenny. 2005. "Corporate Responsibility: The Communication Challenge." Journal of Communication Management 9, no. 2: 108-19.

De Jong, Piet. 2012. "The Health Impact of Mandatory Bicycle Helmet Laws." Risk Analysis: An International Journal 32, no. 5: 782-90.

Douglas, Jacqueline, Alex Douglas, and Barry Barnes. 2006. "Measuring Student Satisfaction at a UK University." Quality Assurance in Education 14, no. 3: 251-67.

Du, Shuili, Chitrabhan B. Bhattacharya, and Sankar Sen. 2010. "Maximizing Business Returns to Corporate Social Responsibility (CSR): The role of CSR Communication." International Journal of Management Reviews 12, no. 1: 8-19. 
Eggen, Paul D., and Don Kauchak. 1993. Educational Psychology: Classroom Connections. Simon \& Schuster Books for Young Readers.

Fishbein, Martin, and Icek Ajzen 2011. Predicting and Changing Behavior: The Reasoned Action Approach. Psychology Press.

Garnelo-Gomez, Irene. 2017. "'I Live Sustainably': Exploring Sustainable Narratives through the Lens of Identity Expression and Motivational Drives." PhD diss., University of Reading.

Giacalone, Robert A., and Kenneth R. Thompson. 2006. "Business Ethics and Social Responsibility Education: Shifting the Worldview." Academy of Management Learning \& Education 5, no. 3 : 266-77.

Golob, Urša, Marko Lah, and Zlatko Jančič. 2008. "Value orientations and consumer expectations of corporate social responsibility." Journal of Marketing Communications 14, no. 2: 83-96.

Groza, Mark D., Mya R. Pronschinske, and Matthew Walker. 2011. "Perceived Organizational Motives and Consumer Responses to Proactive and Reactive CSR." Journal of Business Ethics 102, no. 4: 639-52.

Guolla, Michael. 1999. "Assessing the Teaching Quality to Student Satisfaction Relationship: Applied Customer Satisfaction Research in the Classroom." Journal of Marketing Theory and Practice 7, no. 3: 87-97.

Hemingway, Christine A. 2005. "Personal Values as a Catalyst for Corporate Social Entrepreneurship." Journal of Business Ethics 60, no. 3: 233-49.

Hemingway, Christine A., and Patrick W. Maclagan. 2004. "Managers' Personal Values as Drivers of Corporate Social Responsibility." Journal of Business Ethics 50, no. 1: 33-44.

Henley Business School. 2017. Report to the United Nations Principles for Responsible Management Education 2015/16 \& 2016/17. Accessed June 28, 2018. http://www.unprme.org/reports/HenleyBusinessSchoolUNPRME2017.pdf

Hill, Yvonne, Laurie Lomas, and Janet MacGregor. 2003 "Students' Perceptions of Quality in Higher Education." Quality Assurance in Education 11, no. 1: 15-20.

Jones, Edward Ellsworth, and Harold Gerard. 1967. Foundations of Social Psychology. John Wiley \& Sons Inc.

Jones, Lee W., Robert C. Sinclair, and Kerry S. Courneya. 2003. "The Effects of Source Credibility and Message Framing on Exercise Intentions, Behaviors, and Attitudes: An Integration of the Elaboration Likelihood Model and Prospect Theory 1." Journal of Applied Social Psychology 33, no. 1: 179-96.

Kolb, David. 1984. Experiential Education: Experience as the Source of Learning and Development. Englewood Cliffs, NJ: Prentice-hall. 
Kwon, Mina, Geetanjali Saluja, and Rashmi Adaval. 2015. "Who Said What: The Effects of Cultural Mindsets on Perceptions of Endorser-Message Relatedness." Journal of Consumer Psychology 25, no. 3: 389-403.

Lafferty, Barbara A., and Ronald E. Goldsmith. 1999. "Corporate Credibility's Role in Consumers' Attitudes and Purchase Intentions when a High Versus a Low Credibility Endorser is Used in the Ad." Journal of Business Research 44, no. 2: 109-16.

Larran, Jorge Manuel, Andrades Peña Francisco Javier, and Muriel de los Reyes Maria Jose. 2017. "Analysing the Inclusion of Stand-alone Courses on Ethics and CSR: A Study of the MBA Curricula of the Financial Times Top-ranked Business Schools." Sustainability Accounting, Management and Policy Journal 8, no. 2: 114-37.

Larran, Jorge Manuel and Andrades Peña Francisco Javier. 2014. "Determinants of Corporate Social Responsibility and Business Ethics Education in Spanish Universities." Business Ethics: A European Review 23, no. 2: 139-53.

López-Pérez, M. Eugenia, Iguácel Melero, and F. Javier Sesé. 2017. "Does Specific CSR Training for Managers Impact Shareholder Value? Implications for Education in Sustainable Development." Corporate Social Responsibility and Environmental Management 24, no. 5: 435-48.

Lozano, Josep M., Arenas, Daniel, and Sauquet, Alfons. 2006. "Educational programmes in corporate social responsibility". In Corporate Social Responsibility, Volume 2: Performances and Stakeholders, 241-59. London: Palgrave Macmillan.

MacKenzie, Scott B., and Richard J. Lutz. 1989. "An Empirical Examination of the Structural Antecedents of Attitude Toward the Ad in an Advertising Pretesting Context." The Journal of Marketing: 48-65.

McDonald, Gael M. 2004. "A Case Example: Integrating Ethics into the Academic Business Curriculum." Journal of Business Ethics 54, no. 4: 371-84.

McWilliams, Abagail, Donald S. Siegel, and Patrick M. Wright. 2006. "Corporate Social Responsibility: Strategic Implications." Journal of Management Studies 43, no. 1: 1-18.

Millar, Jill, and Margaret Price. 2018. "Imagining Management Education: A Critique of the Contribution of the United Nations PRME to Critical Reflexivity and Rethinking Management Education." Management Learning 49, no. 3. https://doi.org/10.1177/1350507618759828.

Miller, Joanne M., and Jon A. Krosnick. 2000. "News Media Impact on the Ingredients of Presidential Evaluations: Politically Knowledgeable Citizens are Guided by a Trusted Source." American Journal of Political Science: 301-15.

Morsing, Mette. 2006. "Strategic CSR Communication: Telling Others How Good You Are." In Management Models for Corporate Social Responsibility, 238-46. Berlin, Heidelberg: Springer. 
Murray, Kate, and Ranald Macdonald. 1997. "The Disjunction between Lecturers' Conceptions of Teaching and Their Claimed Educational Practice." Higher Education 33, no. 3: 331-49.

Northcott, Jill. 2001. "Towards an Ethnography of the MBA Classroom: A Consideration of the Role of Interactive Lecturing Styles within the Context of one MBA Programme." English for Specific Purposes 20, no. 1: 15-37.

O’Rourke, James S. 2013. "Corporate Reputation and the Discipline of Management Communication." In The Handbook of Communication and Corporate Reputation, edited by Craig E. Carroll, 7280. Wiley-Blackwell.

Principles for Responsible Management Education (PRME). 2007. "About Us". Accessed May 28, 2018 http://www.unprme.org/about-prme/history/index.php.

Reputation Institute. 2018. "2018 Global RepTrak ${ }^{\circledR}$ - Most Reputable Companies in the World". Accessed June 28, 2018. https://www.reputationinstitute.com/resources/pdf/2018-globalreptrak.

Ruth, Julie A., and Anne York. 2004. "Framing Information to Enhance Corporate Reputation: The Impact of Message Source, Information Type, and Reference Point." Journal of Business Research 57, no. 1: 14-20.

Saraeva, Anastasiya. 2017. "The Interactions between Messages and Stakeholder (dis)identification with Messengers: Exploring Their Moderating Impact on the Links between Perceptions of Corporate Reputation, Organisational (dis)identification, and Behavioural Outcomes." PhD diss., University of Reading.

Setó-Pamies, Dolors, and Eleni Papaoikonomou. 2016. "A Multi-level Perspective for the Integration of Ethics, Corporate Social Responsibility and Sustainability (ECSRS) in Management Education." Journal of Business Ethics 136, no. 3: 523-38.

Sims, Ronald R. 2002. "Business Ethics Teaching for Effective Learning." Teaching Business Ethics 6, no. 4: 393-410.

Stubbs, Wendy, and Jan Schapper. 2011. "Two Approaches to Curriculum Development for Educating for Sustainability and CSR." International Journal of Sustainability in Higher Education 12, no. 3: 259-68.

Tata, Jasmine, and Sameer Prasad. 2015. "CSR Communication: An Impression Management Perspective." Journal of Business Ethics 132, no. 4: 765-78.

Tootoonchi, Ahmad, Paul Lyons, and Abdalla Hagen. 2002. "MBA Students' Perceptions of Effective Teaching Methodologies and Instructor Characteristics." International Journal of Commerce and Management 12, no. 1: 79-93.

Turker, Duygu. 2009. "How Corporate Social Responsibility Influences Organizational Commitment." Journal of Business Ethics 89, no. 2: 189. 
Waddock, Sandra, and Josep M. Lozano. 2013. "Developing more holistic management education: Lessons learned from two programs." Academy of Management Learning \& Education12, no. 2: $265-84$. 